\title{
24. MIOSPORES AND OTHER ACID-RESISTANT MICROFOSSILS FROM THE APTIAN/ALBIAN OF HOLES 400A AND 402A, DSDP-IPOD LEG 48, BAY OF BISCAY
}

\author{
D.J. Batten, Department of Geology and Mineralogy, Marischal College, Aberdeen University, Aberdeen, AB9 1AS, U.K.
}

\section{INTRODUCTION}

The main object of DSDP Leg 48 was to investigate problems concerning the evolution of passive continental margins. To this end, 10 holes were drilled at seven sites in the Bay of Biscay and on the Rockall Plateau. The two sites considered herein lie on the Armorican continental margin in the Bay of Biscay.

Site 400 is situated just south of the Meriadzek Terrace on the northern continental margin of the Bay of Biscay (Figure 1). After washing to 63 meters, the hole was continuously cored to 777.5 meters. Drilling was abandoned in Aptian black shales. Lower Cretaceous (Albian) rocks were first encountered downhole at 656 meters (Core 62). They are overlain unconformably by late Campanian marly nannofossil chalks. The upper part of the Lower Cretaceous unit consists largely of marly nannofossil chalks and carbonaceous marly chalks. The lower part comprises alternating mudstones and marly nannofossil chalks.

Site 402 was drilled in a canyon on the mid-continental slope of the Bay of Biscay, north of the Meriadzek escarpment and the Shambrock Canyon (Figure 1). The hole was washed down to 137 meters and then cored continuously to 469.5 meters terminal depth in Aptian limestones. Lower Cretaceous strata of Albian age were first encountered at 175 meters; and consist of lithified rocks of variable, though largely limestone and claystone, facies. From 232 to 469.5 meters the section is mainly composed of marly limestones, mudstones, and marly chalks, all of which are carbonaceous. Strata of middle Eocene age rest unconformably on this Aptian-Albian sequence.

The frequent occurrence of carbonaceous mudstones and chalks in the Aptian-Albian rocks at both sites has caused this interval to be known as the "black shales series." Black shales have been reported from widely scattered localities in both the South and southern North Atlantic. Their recovery from the Bay of Biscay extends their previously known areal distribution northwards.

Palynological slides were prepared at the Institute of Geological Sciences, Leeds, England, from 13 samples representing 12 cores from Hole $400 \mathrm{~A}$ and 24 samples representing 22 cores from Hole $402 \mathrm{~A} ; 3$ or 4 slides were made from most samples. Two slides from all but two samples (which did not yield sufficient residue to permit examination of more than one) were studied. Dr. R.J. Davey (I.G.S., Leeds) examined the other slides; his report on the dinoflagellate cysts is included in this volume. In addition to the study of miospores for biostratigraphic analysis, the relative abundance of other components of the organic residues were noted for paleoecological purposes.

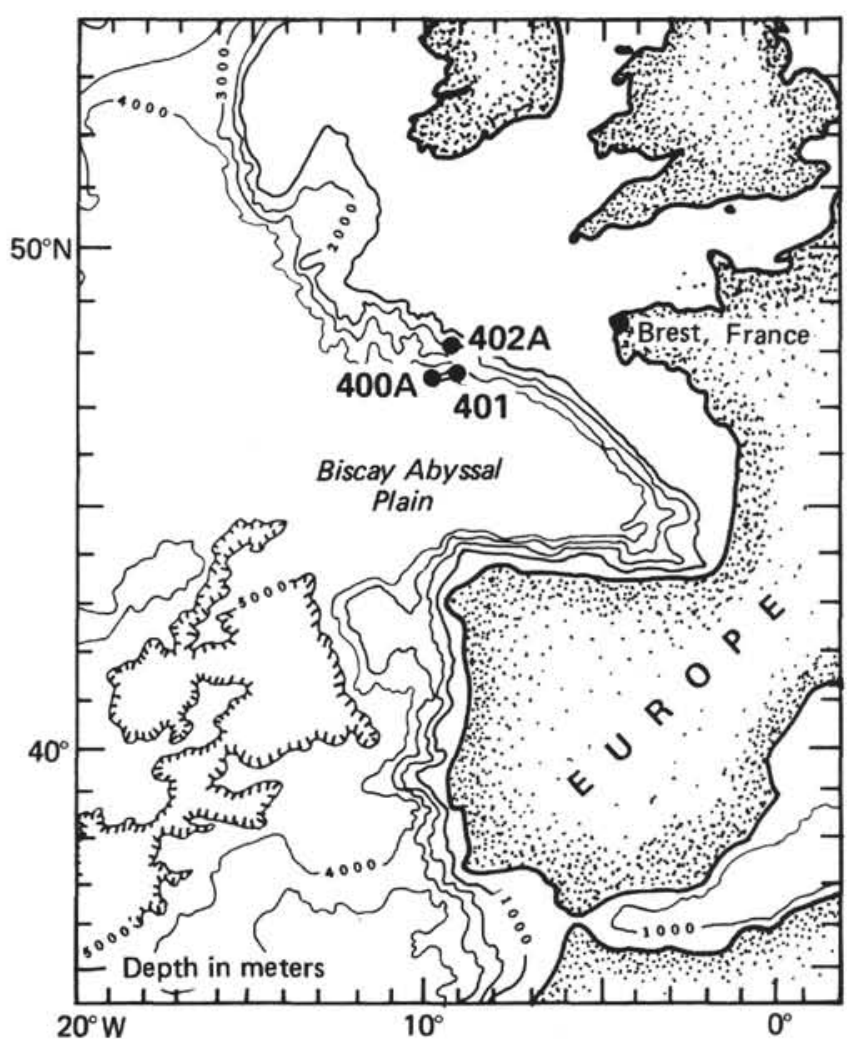

Figure 1. Location of Sites 400 and 402, IPOD Leg 48.

Summaries of the results are included in the Site 400 and 402 chapters in this volume.

All the slides are housed in the palynological collection of the Institute of Geological Sciences, Leeds. All figured specimens have been assigned MPK numbers. I am grateful to Dr. Davey for making them available to me. Table 1 lists the samples processed and the I.G.S. palynological preparation numbers, prefixed CSA.

\section{PALYNOSTRATIGRAPHY}

Most of the miospores recorded have already been described in the literature and a few of these are illustrated here (Plates 1 and 2). Many are, however, of little use for subdividing the Aptian-Albian successions of the two sites because either they are long ranging or their ranges are uncertain. Included in the latter category are a few species which are apparently new and have yet to be formally described. Age determinations are based herein primarily on assessments of the total miospore composition of the palynological preparations rather than on individual taxa. 
TABLE 1

Samples Processed and the I.G.S. Palynological Preparation Numbers

\begin{tabular}{|c|c|}
\hline $\begin{array}{c}\text { Sample } \\
\text { (Interval in } \mathrm{cm} \text { ) }\end{array}$ & CSA Number \\
\hline \multicolumn{2}{|l|}{ Hole $400 \mathrm{~A}$} \\
\hline $62-2,41-43$ & 1962 \\
\hline $62-4,111-113$ & 1963 \\
\hline $63-2, \quad 80-83$ & 1964 \\
\hline $64-3, \quad 52-55$ & 1965 \\
\hline $65-2, \quad 19-22$ & 1966 \\
\hline $66-3, \quad 55-60$ & 1967 \\
\hline $67-0$ & 1968 \\
\hline $68-2, \quad 24-26$ & 1969 \\
\hline $69-1, \quad 84-86$ & 1970 \\
\hline $70-0$ & 1971 \\
\hline $71-1,111-113$ & 1972 \\
\hline $72-3, \quad 40-42$ & 1973 \\
\hline $74-1, \quad 4-6$ & 1974 \\
\hline \multicolumn{2}{|l|}{ Hole $402 \mathrm{~A}$} \\
\hline $11-4,105-108$ & 1994 \\
\hline $12-1, \quad 99-103$ & 1995 \\
\hline $13-2, \quad 93-96$ & 1996 \\
\hline $14-3, \quad 87-89$ & 1997 \\
\hline $23-26$ & 1998 \\
\hline $16-2, \quad 34-37$ & 1999 \\
\hline $17-2,119-122$ & 2000 \\
\hline $18-4, \quad 75-78$ & 2001 \\
\hline $19-4, \quad 81-84$ & 2002 \\
\hline $20-4$ & 2003 \\
\hline $21-7, \quad 10-12$ & 2004 \\
\hline $22-6, \quad 87-91$ & 2005 \\
\hline $23-6, \quad 35-38$ & 2006 \\
\hline $24-5, \quad 13-16$ & 2007 \\
\hline $25-5$ & 2008 \\
\hline $26-1$ & 2009 \\
\hline $60-63$ & 2010 \\
\hline $15-19$ & 2011 \\
\hline $32-7, \quad 0-4$ & 2012 \\
\hline $33-6, \quad 35-38$ & 2013 \\
\hline $34-3, \quad 94-98$ & 2014 \\
\hline $35-1,108-111$ & 2015 \\
\hline $35-3, \quad 34-38$ & 2016 \\
\hline $35-3, \quad 69-72$ & 2017 \\
\hline
\end{tabular}

\section{Hole 400A}

Many of the miospores recorded from the cored Aptian-Albian section of Hole $400 \mathrm{~A}$ are long-ranging bisaccate pollen grains and weakly sculptured triradiate spores which have no value in palynostratigraphic subdivision. Strongly sculptured triradiate spores which are known to be biostratigraphically important are rare. Despite the fact that the significance of some species of Cicatricosisporites (including forms which have the characters of Costatoperforosporites and Appendicisporites) and other taxa has yet to be ascertained, the following age assessments have been made.

A late Albian age is suggested for the interval covered by Samples $62-2,41-43 \mathrm{~cm}$ to $63-2,80-83 \mathrm{~cm}$ on the basis of forms which have the characters of Alisporites elongatus Kemp, Parvisaccites rugulatus Brenner (Plate 2, Figures 2 and 3), Camarozonosporites insignis Norris and Taurocusporites spackmanii Brenner (Plate 1, Figure 4), and on the absence of pollen grains which can be positively identified as Tsugaepollenites dampieri (Balme) and $T$. trilobatus (Balme). Among other taxa recorded are Gleichoniidites senonicus Ross, Osmundacidites wellmanii Couper, Araucariacites australis Cookson, Cerebropollenites mesozoicus (Couper), Parvisaccites radiatus Couper (Plate 1, Figures 16-18) and species of Converrucosisporites, Klukisporites, Lycopodiumsporites, Patellasporites, Polypodiaceoisporites, Undulatisporites, Classopollis, and Cycadopites.

In Sample 64-3, 52-55 $\mathrm{cm}$ both Tsugaepollenites dampieri (Plate 1, Figure 20) and T. trilobatus occur in association with Converrucosisporites variverrucatus (Couper), a form similar to Foraminisporis wonthaggiensis (Cookson and Dettmann), Sestrosporites pseudoalveolatus (Couper), Staplinisporites caminus (Balme) and other taxa. This association suggests that mid-Albian strata have been penetrated.

Polypodiaceoisporites foveolatus (Couper) is relatively common at 67-0 and below. Associated taxa from 67-0 include Coronatispora valdensis (Couper), Ceratosporites parvus Brenner, species closely related morphologically to both $C$. distalgranulatus (Couper) and Ornamentifera as well as many of the forms seen in the stratigraphically higher samples. This association suggests that early Albian strata might have been penetrated though a late Aptian age cannot be ruled out for this level. A similar association together with the occurrence of Crybelosporites vectensis Kemp is consistent with a late Aptian age for Sample 70-0.

The preparations examined from deeper samples contain few biostratigraphically useful taxa. An assignment of an early Aptian age for the interval can be suggested on negative evidence only, in particular on the absence of Ceratosporites distalgranulatus. On present evidence, the occurrence of Polypodiaceoisporites foveolatus in Sample 74-1, 4-6 cm suggests that this sample is not older than the early Aptian, D. deshayesi Zone. Densoisporites microrugulatus Brenner and species of Clavifera and Lycopodiacidites are among the taxa recorded that were not noted in preparations from the overlying strata.

\section{Hole 402A}

A scarcity of miospores with stratigraphically restricted ranges and (perhaps extensive) reworking of Aptian material into the Albian makes it difficult to subdivide the penetrated section, on miospores alone.

The interval covered by the Samples $11-4,105-108 \mathrm{~cm}$ to $25-5,5-8 \mathrm{~cm}$ yielded a relatively large number of taxa, the general aspect of the entire assemblage indicating an Albian age. Comparison with palynomorph assemblages recovered from the English Aptian-Albian succession (Kemp, 1970; Batten, 1976; and unpublished data) suggests that Samples 11-4, 105-108 $\mathrm{cm}$ to $13-2,93-96 \mathrm{~cm}$ might be of middle Albian age, although the possibility that they are late Albian cannot be dismissed. The following are among the taxa recorded: Ceratopsporites distalgranulatus, Densoisporites microrugulatus (Plate 1, Figure 8) Lycopodiumsporites clavatoides Couper, Ornamentifera echinata (Bolkhovitina), Osmundacidites wellmanii, Pilosisporites trichopapillosus (Thiergart), Polypodiaceoisporites foveolatus (Plate 1, Figures 9 and 10), forms closely related 
to Microreticulatisporites uniformis Singh and Trilobosporites humilis Delcourt and Sprumont, Araucariacites australis, Cerebropollenites mesozoicus (Plate 1, Figure 13), Parvisaccites radiatus, Perinopollenites elatoides Couper, and Tsugaepollenites dampieri as well as species of Appendicisporites, Camarozonosporites, Cicatricosisporites, Cingutriletes, Gleicheniidites, Klukisporites, and Lycopodiacidites.

The samples from $15-6,23-26 \mathrm{~cm}$ to $22-6,87-91 \mathrm{~cm}$ are more clearly middle or middle-early Albian. Some of the taxa listed above and the following are associated in this interval: Acanthotriletes varispinosus Pocock (Plate 1, Figure 3), Baculatisporites comaumensis (Cookson), Camarozonosporites insignis, Ceratosporites parvus, Concavissimisporites crassatus (Delcourt and Sprumont) (Plate 1, Figure 12), Coronatispora valdensis, Gleicheniidites apilobatus Brenner (Plate 1, Figures 1 and 2), G. senonicus, Ornamentifera baculata Singh, Sestrosporites pseudoalveolatus (Plate 1, Figures 5 and 6), Aequitriradites spinulosus (Cookson and Dettmann) (Plate 1, Figure 15), Eucommiidites stuartii Kemp (Plate 1, Figure 19), and forms closely comparable to Kuylisporites lunaris Cookson and Dettmann, Lycopodiumsporites marginatus Singh, Schizosporis reticulatus Cookson and Dettmann, and Parvisaccites rugulatus (Plate 2, Figure 1).

Additional taxa recorded from Samples $23-6,35-38 \mathrm{~cm}$ to $25-5,5-8 \mathrm{~cm}$ include Foveosporites subtriangularis (Brenner), Foraminisporis asymmetricus (Cookson and Dettmann) (Plate 1, Figure 7), Tsugaepollenites trilobatus, and questionable Crybelosporites vectensis. The general aspect of the assemblages compares closely with that of assemblages recovered from the early Albian of southern England. If reliance is placed on this correlation then the middle-early Albian boundary could lie between Samples $22-6,87-91 \mathrm{~cm}$ and $23-6,35-38 \mathrm{~cm}$.

Among the taxa identified from Samples 30-6, 60-63 cm to $35-3,69-72 \mathrm{~cm}$ are Clavifera triplex (Bolkhovitina) (Plate 1, Figure 11), a species of Tigrisporites described by Kemp (1970) as Lycopodiumsporites glebulentus, Matonisporites phlebopteroides Couper (Plate 1, Figure 14), Aequitriradites verrucosus (Cookson and Dettmann), Cooksonites variabilis Pocock, and species of Pilosisporites. This association, combined with the absence of Camarozonosporites insignis and the scarcity of Polypodiaceoisporites, Ornamentifera, and other taxa, indicates an Aptian age at least for this interval if not for the stratigraphically higher Sample 26-1, 9-14 cm. An early-late Aptian boundary between Samples 32-7, 0-4 cm and $33-6,35-38 \mathrm{~cm}$ can only be inferred from the miospores on doubtful negative evidence. A fuller discussion of this and other palynostratigraphic problems associated with the Aptian-Albian of this site would be premature and must await more detailed examination of the miospore content of the assemblages recovered.

\section{PALYNOLOGICAL FACIES}

The character of the palynological facies has had to be assessed on the basis of observation of sieved, oxidized residues, these being the only preparations presently available. This means that very finely particulate organic matter will have been removed from the residues before slide preparation, and that some of the amorphous organic matter, particularly that of terrestrial (land plant) origin will be underrepresented because the laboratory oxidation process will have removed some if not most of it. Despite these limitations, it is still possible to comment usefully on the acid-resistant component (kerogen) of the processed samples with respect to environment of deposition. Indeed, some assemblage characters such as the relative abundance and state of preservation of miospores, phytoplankton and other entities are easier to determine from "clean" oxidized than unoxidized preparations.

\section{Hole 400A}

The 13 processed samples from this site are mostly calcareous. They comprise mudstones and chalks, some rich in organic matter, and a carbonaceous limestone.

The four carbonaceous mudstones yielded some of the largest organic residues. Miospores are clearly more common than phytoplankton in these and in the carbonaceous limestone. By contrast, phytoplankton are clearly dominant in three of the four residues from the marly nannofossil chalks. Miospores are dominant in the other nannofossil chalk and appear to be rather more common than the dinocysts in three of the four remaining samples. Foraminiferal linings occur sporadically, most often in the carbonaceous mudstones.

Woody tissues in the assemblages consist largely of fusinite and vitrinite in varying proportions, but the vitrinite group appears to be generally dominant. Relative abundances of tracheids and fusain do not seem to show any consistent relationships with lithotype, but the organically rich samples yielded small quantities of lignitic and pale brown amorphous matter.

Two kinds of amorphous organic matter are readily distinguishable in palynological preparations. The first is resistant to oxidation and generally considered to be of marine origin. The second may be partially or entirely removed by oxidizing agents in the laboratory and is mostly decomposed land plant matter. The fact that there is relatively little amorphous debris in the preparations from Hole 400A suggests that the bulk of the finely divided material in the samples is of terrestrial (humic) rather than marine origin.

The preservation of the miospores is in general rather poor, although well-preserved specimens do occur and are sometimes common. Crystals or relict structures of pyrite may be present in their walls. By contrast, the dinocysts are generally in a good or fair state of preservation. The reasons for these differences are uncertain, but it is possible that the poor preservation of the miospores is the result of prolonged oxidation and microbial activity during transport from the source area. Many show corrosion features similar to those illustrated by Elsik (1966, 1968, p1.1) and others. Although evidence for reworking is stronger at Hole $402 \mathrm{~A}$, the miospores could conceivably have been recycled several times before finally coming to rest at this site. Being of marine origin, the dinocysts would not have been subjected to the same kind of recycling and the processes of degradation which accompany it, though they could not have escaped local reworking. 
I suggest that the poor preservation of the miospores indicates that deposition of the Aptian-Albian sediments at Hole 400A occurred relatively far from source. Other evidence supports this conclusion. All the preparations contain many bisaccate pollen grains; indeed these grains frequently dominate the palynomorph assemblages, and in all cases they are much more common than the triradiate spores. The latter are mostly small (maximum diameter $<50 \mu \mathrm{m}$ ), thin-walled, and smooth or only lightly sculptured. Plant cuticles are rare, and megaspores are only occasionally represented by small fragments of exine. It may be assumed that most of the cuticles, megaspores and large, thick-walled heavily sculptured miospores settled out with coarser mineral detritus nearer shore. Other indicators of near shore deposition, such as foraminiferal linings and peridinacean cysts, are also scarce. Fluctuations in the relative proportions of bisaccates, triradiate spores, and dinocysts indicate variable influence of the products of the terrestrial flora on the depositional site which in turn may also reflect, to some extent, varying distance from shore. Whereas it is certain that deposition occurred in "open marine" conditions and probably in deeper waters than at Hole 402A, it is not possible, solely on palynological grounds, to determine the depth at which deposition took place.

\section{Hole 402A}

All 24 samples from the Aptian-Albian of this site are calcareous, most being calcareous mudstones and marly limestones containing varying amounts of organic matter. All of the assemblages from Sample 11-4, 105-108 cm down to Sample 31-6, 15-19 $\mathrm{cm}$ have a general aspect which is remarkably uniform. Miospores are clearly more common than dinocysts in 11 samples and appear to be the dominant component in the majority of the remainder. Inner linings of foraminifers were recorded from 21 samples and are common in 9 of these. Fungal spores and structures, including forms referable to the Microthyriales, were noted in 13 but are never common. Tasmanitids were seen in 6 , and isolated specimens of Botryococcus, presumably transported from fresh water environments, in 5. Megaspore fragments also occur sporadically.

The woody matter is largely fusinite and vitrinite, and much of it consists of tracheidal debris. Brown wood (lignitic) fragments and other tissues are usually present but rarely common (two samples only). Amorphous organic matter is also usually present, but is only common in one sample $(13-2,93-96 \mathrm{~cm})$. In general this matter appears to be mostly sapropelized vascular plant debris, but an algal component may also be present.

The dinoflagellate cyst assemblages are relatively diverse, and individuals are generally well to fairly well preserved, but, as for Hole $400 \mathrm{~A}$, there is a considerable variation in the preservation state of the miospores. Well-preserved specimens do occur, and may even be common, but generally the condition of the miospores is poor (Plate 2, Figures 4-13) or at best only fair, and crystals or relict structures of pyrite are common in their walls, particularly in 13 of the assemblages. This fact, together with the uniformity of the palynological facies through this largely Albian interval, suggests that much of the organic matter in these preparations might have been subjected to oxidation and microbial decay through reworking. That reworking occurred is indicated by the presence in the Albian of palynomorphs which normally occur only in Aptian (and older) strata (see Davey, this volume).

From Samples $32-7,0-4 \mathrm{~cm}$ to $35-3,69-72 \mathrm{~cm}$ the palynological facies are more varied. This suggests that their composition has not been as greatly affected by reworked material. It is not yet possible to consider in detail the relationships between the palynofacies and the lithofacies, because an insufficient number of samples has been examined. However, by taking into account the composition of the assemblages from both this interval and the overlying section a few comments on the environment of deposition at this site during the Aptian and Albian can be made.

Perhaps the most important feature of the assemblages is that miospores are abundant in the majority, implying that deposition occurred relatively near shore (and therefore probably also in "shallow"' water). This fact also suggests that Hole 402A was closer to the source flora than Hole $400 \mathrm{~A}$. Such an interpretation is supported by the greater diversity of the triradiate spore assemblages than at Hole $400 \mathrm{~A}$, the larger numbers of foraminiferal linings, the abundance of woody tissues, the (albeit sporadic) occurrence of megaspore and cuticle fragments, the consistent presence of acritarchs and the abundance of peridinacean cysts.

\section{PALYNOMORPH COLOR AND SOURCE POTENTIAL FOR PETROLEUM}

The bulk of the acid-resistant organic matter recovered appears to be of terrestrial (land plant) origin. The amount of sapropelized plant debris that has been removed by the laboratory preparation procedure cannot be ascertained, but to judge from the lithological descriptions of the cores (elsewhere in this volume), some of the facies probably contain sufficient sapropelized matter for them to have potential as a source for both oil and gas. However, the palynomorphs are predominantly pale in color (pale yellow, yellow, light brownish yellow, yellowish orange) indicating that the organic matter has not been subjected to much thermal alteration. This in turn indicates that, at best, only minor quantities of oil and gas could have been generated.

\section{REFERENCES}

Batten, D.J., 1976. Aptian and Albian palynomorph assemblages from southern England, Abstracts, 4th Internat. Palynol. Conf., Lucknow, India., p. 11.

Elsik, W.C., 1966. Biologic degradation of fossil pollen grains and spores, Micropaleontology, v. 12, p. 515-518. 1968. Palynology of a Paleocene Rockdale lignite, Milam County, Texas. I. Morphology and taxonomy, Pollen Spores, v. 10, p. 263-314.

Kemp, E.M., 1970. Aptian and Albian miospores from southern England, Palaeontographica, v. 131B, p. 73-143. 



\section{PLATE 1}

Figures 1, 2 Gleicheniidites apilobatus Brenner.

1. $\times 500$

2. $\times 1000$. MPK 2045, Sample 402-17-2, 119-122 cm. Preparation CSA 2000/RD4.

Figure 3 Acanthotriletes varispinosus Pocock; $\times 1000$. MPK 2046, Sample 402A-17-2, 119-122cm. Preparation CSA 2000/RD4.

Figure 4 Taurocusporites spackmanii Brenner; $\times 1000$. MPK 2047, Sample 400A-62-2, 41-43cm. Preparation CSA 1962/RD2.

Figures 5,6 Sestrosporites pseudoalveolatus (Couper).

5. $\times 500$. MPK 2048, Sample 402A-18-4, 75-78 cm. Preparation CSA 2001/RD4.

6. $\times 1000$. MPK 2049, Sample 402A-24-5, 13-16 cm. Preparation CSA 2007/RD4.

Figure 7 Foraminisporis asymmetricus (Cookson and Dettmann); $\times 1000$. MPK 2050, Sample 402A-23-6, 35-38cm. Preparation CSA 2006/RD4.

Figure 8 Densoisporites microrugulatus Brenner; $\times 1000$. MPK 2051, Sample 402A-18-4, 75-78cm. Preparation CSA 2001/RD4.

Figures 9, 10 Polypodiaceoisporites foveolatus (Couper); $\times 1000$. MPK 2052, Sample 402A-15-6, 23-26cm. Preparation CSA 1998/RD4.

Figure $11 \quad$ Clavifera triplex (Bolkhovitina); $\times 500$. MPK 2053, Sample 402A-31-6, 15-19cm. Preparation CSA 2011/RD4.

Figure 12 Concavissimisporites crassatus (Delcourt and Sprumont); $\times 500$. MPK 2054, Sample 402A-15-6, 23-26cm. Preparation CSA 1998/RD4.

Figure 13 Cerebropollenites mesozoicus (Couper); $\times 500$. MPK 2055, Sample 402A-35-1, $108-111 \mathrm{~cm}$. Preparation CSA 2015/RD4.

Figure 14 Matonisporites phlebopteroides Couper; $\times 500$. MPK 2056, Sample 402A-31-6, $15-19 \mathrm{~cm}$. Preparation CSA 2011/RD4.

Figure 15 Aequitriradites spinulosus (Cookson and Dettmann); $\times 500$. MPK 2057, Sample 402A-15-6, 23-26cm. Preparation CSA 1998/RD4.

Figures 16-18 Parvisaccites radiatus Couper; $\times 500$.

16. MPK 2058, Sample 400A-62-2, 41-43cm. Preparation CSA 1962/RD2.

17. MPK 2059, Sample 400A-72-3, 40-42cm. Preparation CSA 1973/RD2.

18. MPK 2060, Sample 400A-62-2, 41-43cm. Preparation CSA 1962/RD2.

Figure 19 Eucommiidites stuartii Kemp; $\times 1000$. MPK 2061, Sample 402A-17-2, $119-122 \mathrm{~cm}$. Preparation CSA 2000/RD4.

Figure 20 Tsugaepollenites dampieri (Balme); $\times 500$. MPK 2062, Sample 400A-70-0. Preparation CSA 1971/RD2. 
PLATE 1
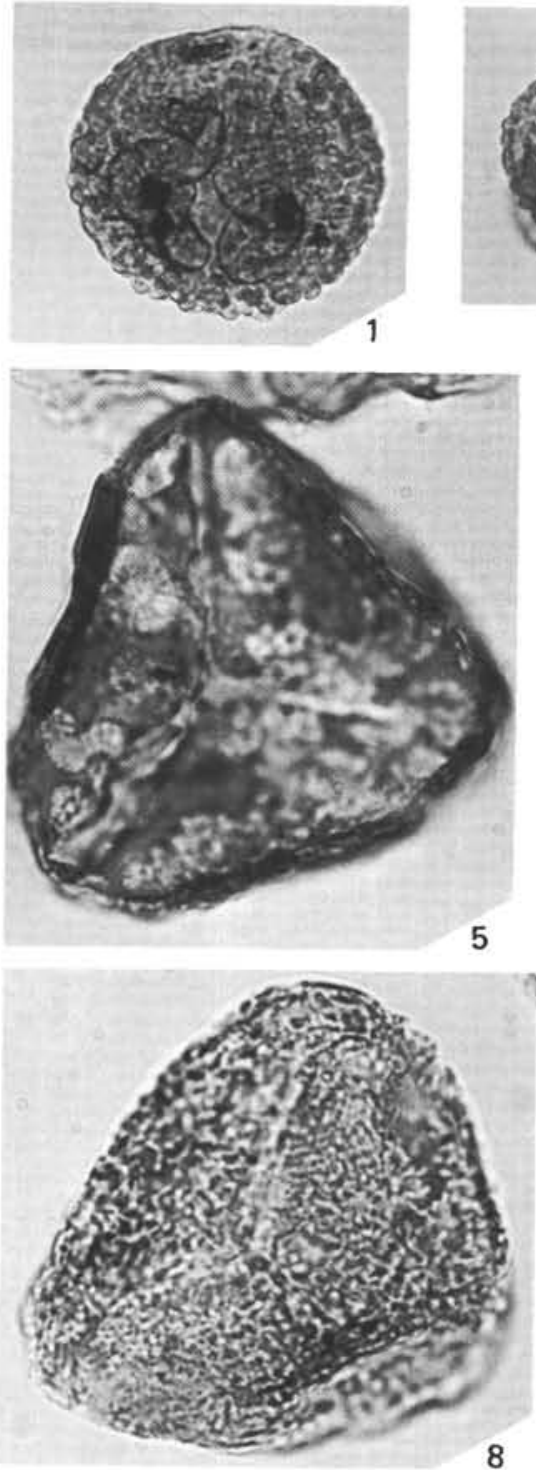
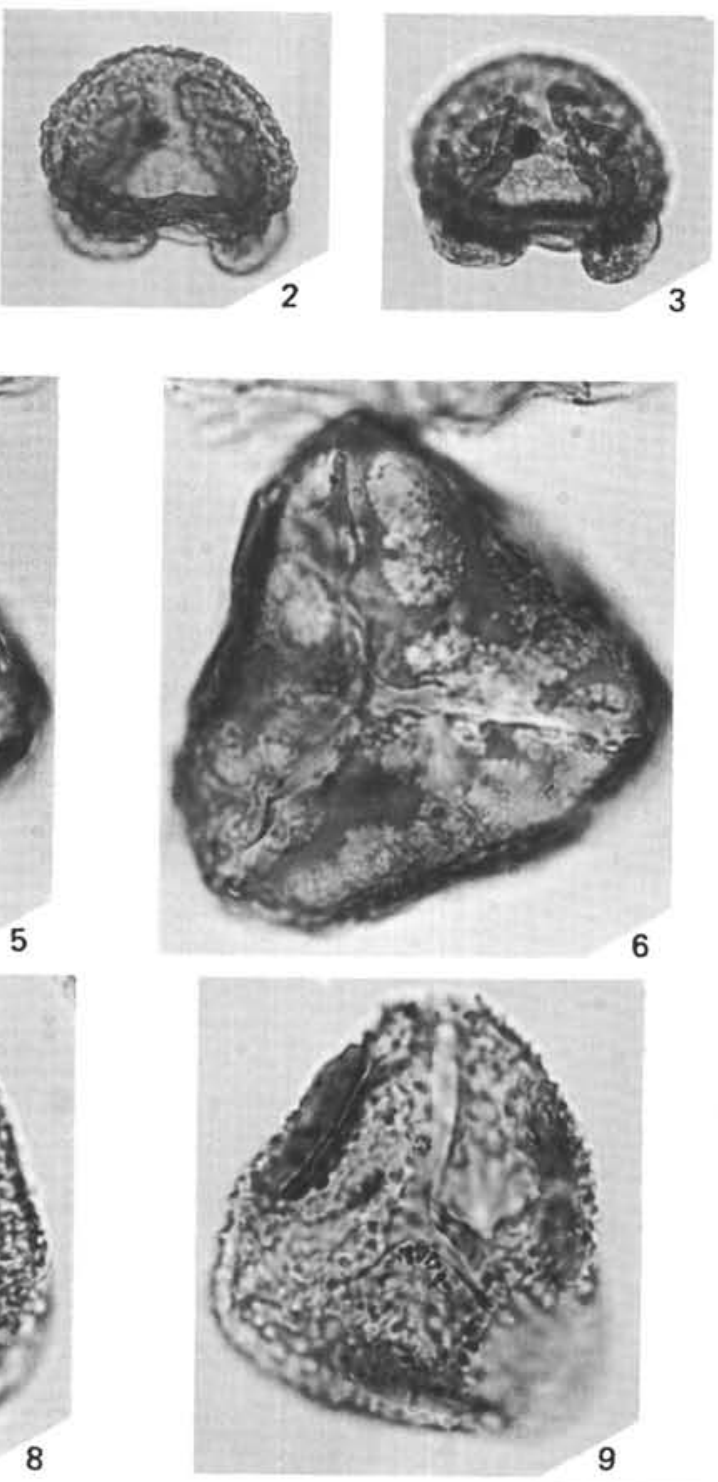
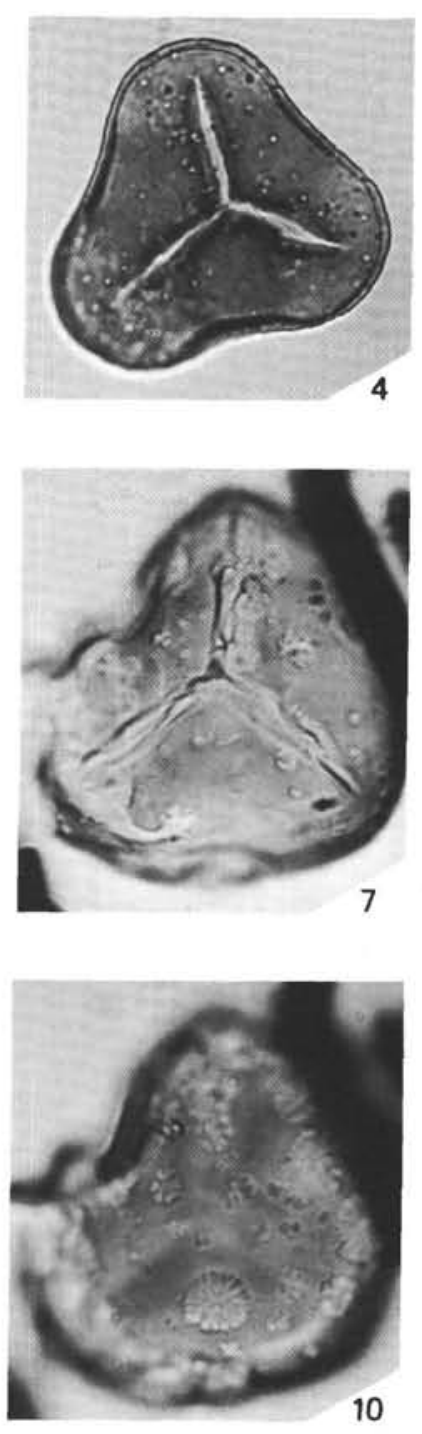
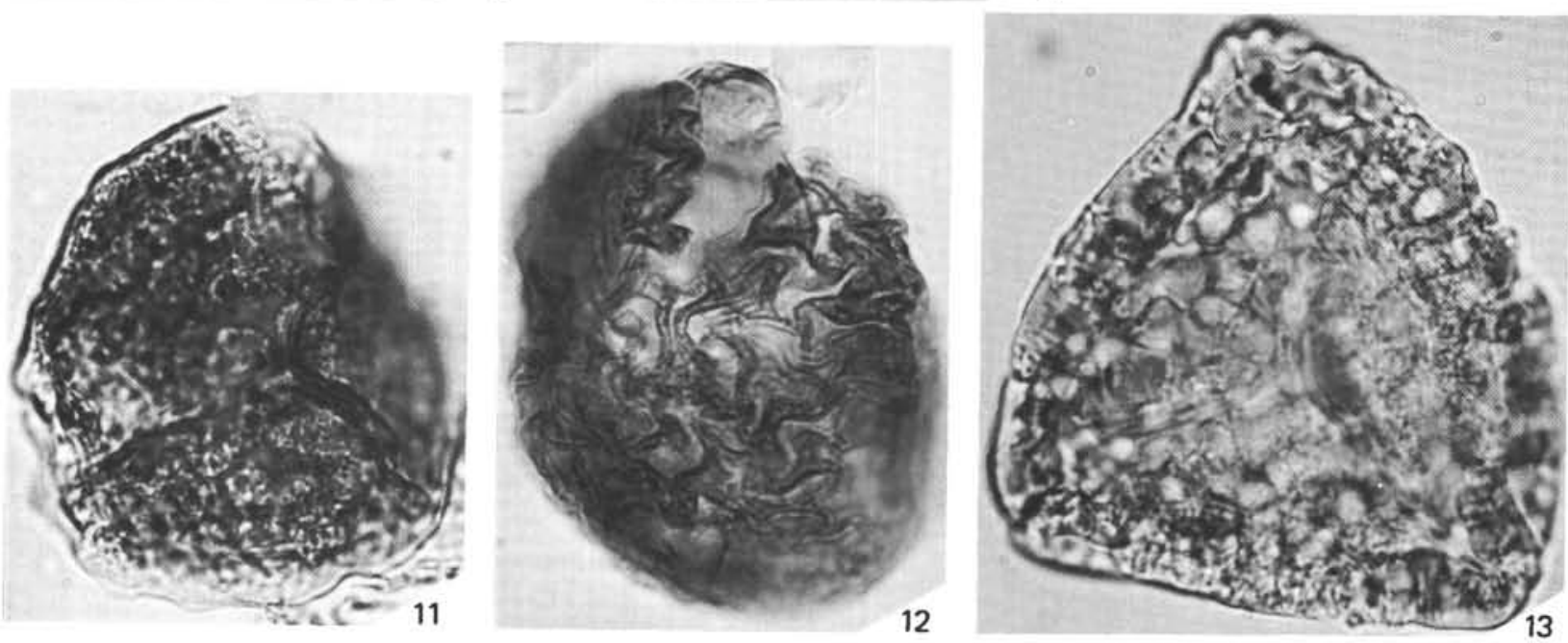


\section{PLATE 2}

Figures 1-3 Parvisaccites rugulatus Brenner; $\times 500$.

1. MPK 2063, Sample 402A-35-3, 34-38cm. Preparation CSA 2016/RD4.

2, 3, MPK 2064, Sample 400A-62-2, 41-43cm. Preparation CSA 1962/RD2.

Figures 4-13 Degraded and corroded specimens.

Figure 4 Cyathidites; $\times$ 500. MPK 2065, Sample 402A-15-6, 23-26cm. Preparation CSA 1998/RD4.

Figures 5,6 ?Deltoidospora; $\times 1000$. MPK 2066, Sample 402A-18-4, 75-78cm. Preparation CSA 2001/RD4.

Figures 7, 10 Deltoidospora; $\times 1000$. MPK 2067, Sample 402A-23-6, 35-38cm. Preparation CSA 2006/RD4.

Figure 8 ?Deltoidospora; $\times 1000$. MPK 2068, Sample 402A-19-4, 81-84cm. Preparation CSA 2002/RD4.

Figure 9 Ornamentifera echinata (Bolkhovitina); $\times 1000$. MPK 2069, Sample 402A-23-6, 35-38cm. Preparation CSA 2006/RD4.

Figure 11 Sestrosporites pseudoalveolatus (Couper); $\times 1000$. MPK 2070, Sample 402A-19-4, 81-84cm. Preparation CSA 2002/RD4.

Figure 12 Lycopodiacidites; $\times 1000$. MPK 2071, Sample 402A-23-6, 35-38cm. Preparation CSA 2006/RD4.

Figure 13 Polypodiaceoisporites; $\times 1000$. MPK 2072, Sample 402A-19-4, 81-84cm. Preparation CSA 2002/RD4. 
PLATE 2
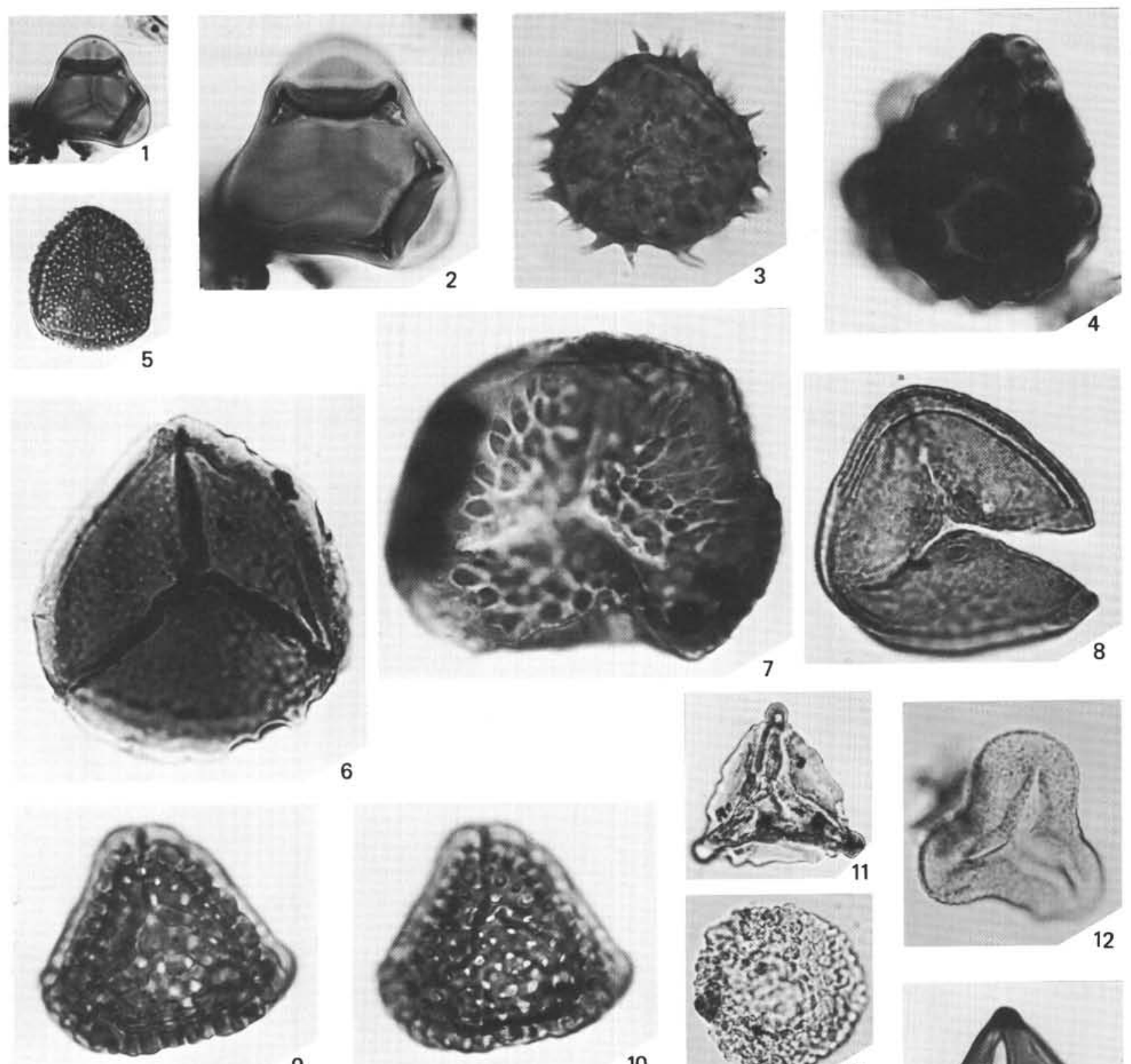

9

10
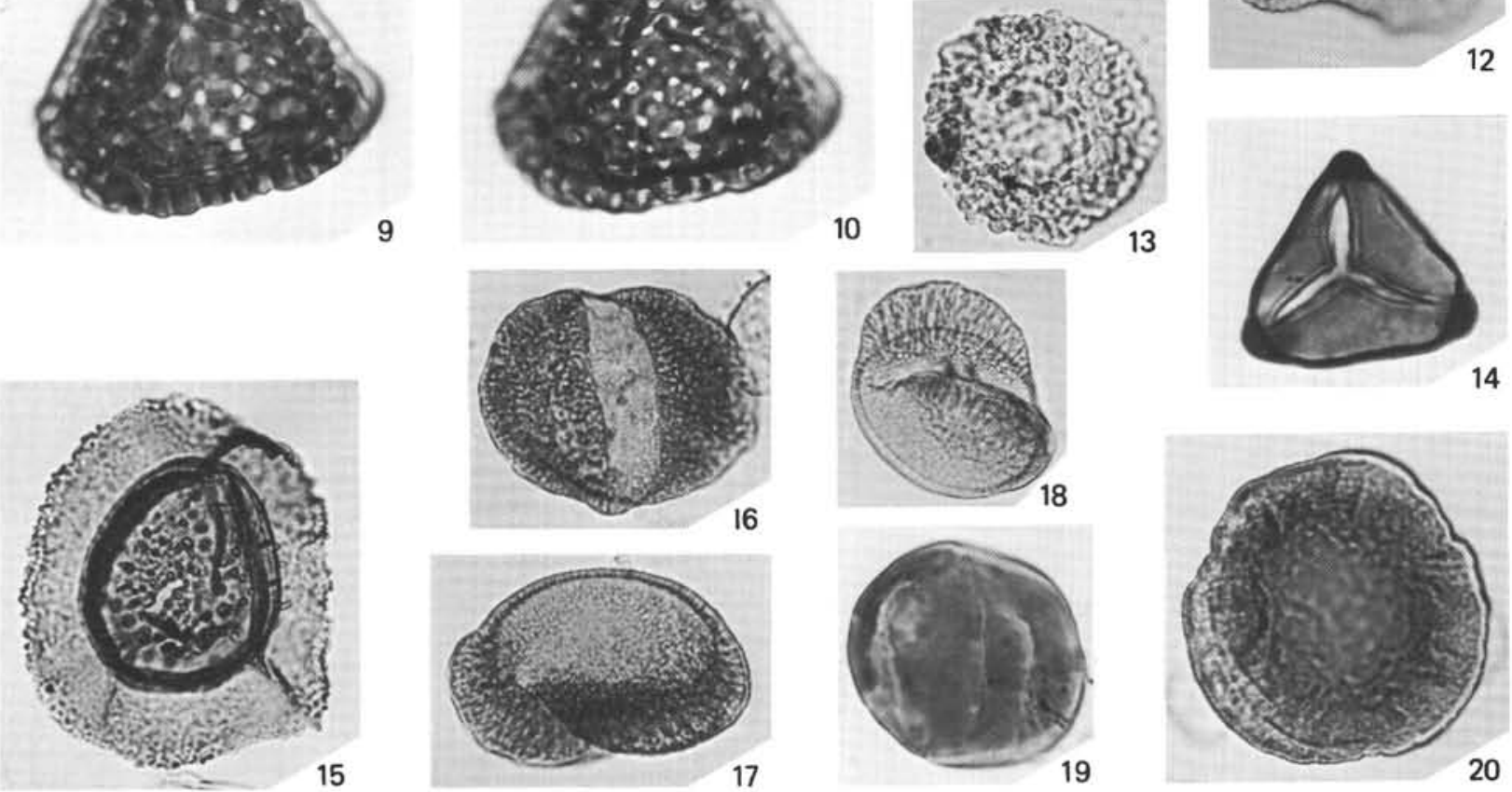